\title{
Honoring Daniel Simberloff: an unwavering champion of invasion biology
}

\author{
Sara E. Kuebbing • Laura A. Meyerson
}

Published online: 22 November 2018

(C) Springer Nature Switzerland AG 2018

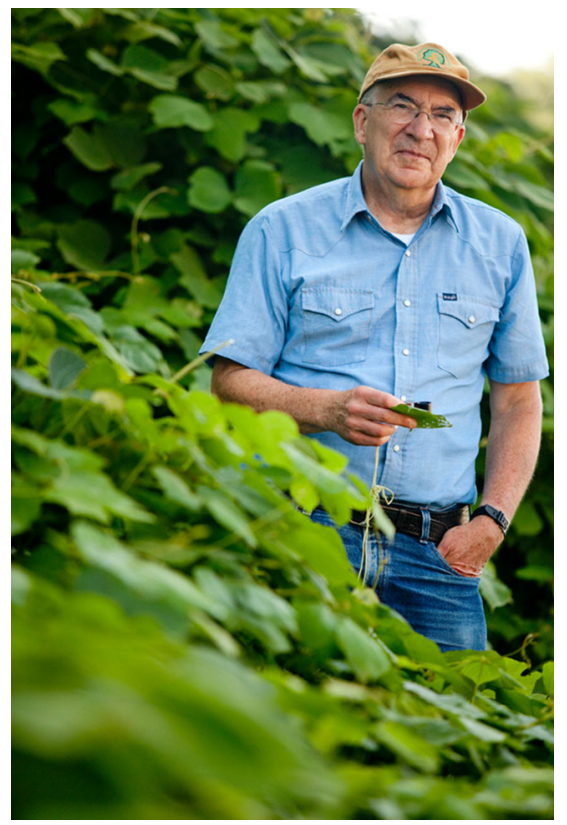

Photo courtesy the University of Tennessee, Knoxville

S. E. Kuebbing $(\bowtie)$

Department of Biological Sciences, University of Pittsburgh, Pittsburgh, PA 15260, USA

e-mail: sara.kuebbing@pitt.edu

L. A. Meyerson

Department of Natural Resources Science, University of Rhode Island, Kingston, RI 02881, USA

e-mail: lameyerson@uri.edu
Daniel Simberloff has composed many tributesincluding in the pages of this journal-honoring the contributions of other scientists to invasion biology. Those Simberloff has honored include Charles Elton who authored the seminal monograph The Ecology of Invasions by Animals and Plants (Simberloff 2011a; Meyerson and Simberloff 2017), Aldo Leopold, whose thoughtful and frequent writings on nonnative species sounded early alarms on their potential ecological impacts (Simberloff 2012), and Hal Mooney, who catalyzed the modern study of invasion biology (Simberloff et al. 2017). These writings demonstrate Simberloff's depth and breadth of knowledge about the history of invasion biology and highlight his long-term commitment to the study of nonnative species.

It is only fitting that we now turn the spotlight to Daniel Simberloff to honor his many contributions to invasion biology. Here, we introduce The Simberloff Award for Outstanding Presentation, which is named to recognize Simberloff's many contributions to the study of nonnative species. The award will be given annually to two students at the Ecological Society of America's annual meeting who embody Simberloff's creativity, intelligence, and passion for studying and understanding the biology of nonnative organisms. Here, we highlight three themes about how ecologists-including students-should approach ecological research that have emerged throughout 
Simberloff's long, productive, and comprehensive career in ecology and invasion biology.

It is not hard to justify naming an award in invasion biology in Simberloff's honor. He is currently the Gore Hunger Professor of Environmental Studies at the University of Tennessee, Knoxville and has been the Editor-in-Chief of this journal since 2008. He has authored over 400 publication on ecology, biogeography, evolution, conservation biology, ecosystem management, history, philosophy, and invasion biology and has been cited over 68,150 times (as of August 14, 2018). Likewise, he edited the 800-page Encyclopedia of Biological Invasions (Simberloff and Rejmánek 2011) and authored the popular science book Invasive Species: What Everyone Needs to Know (Simberloff 2013). He was a recipient of the Eminent Ecologist Award by the Ecological Society of America in 2006, elected to the U.S. National Academy of Sciences in 2012, awarded the Ramon Margalef Prize in Ecology in 2012, the SEC Faculty Achievement Award in 2014, and the Wallace Prize of the International Biogeographical Society in 2015. These accolades signify a lifetime of contributions of a brilliant and dedicated scientist.

Today Simberloff is widely recognized for his contributions to Invasion Biology and as a leading voice on the conservation importance of mitigating and managing the impacts of nonnative species. However, to fully appreciate Simberloff's contributions to the field, we must discuss Simberloff's contributions to ecology and how convictions formed and expressed in his early ecological career shaped the direction and the success of the field of Invasion Biology.

Simberloff's early research did not explicitly address nonnative species or conservation. Instead, he viewed species' invasion as an interesting extension of his research on how communities gain and lose species (Simberloff 2013; Grason 2014) and thought of invasions as unplanned experiments on the colonization of sites by new species (Simberloff 2013; Santos 2016). At the time, this was likely how most scientists considered nonnative species (if they thought about them at all), because, as Simberloff himself has extensively reviewed, academic interest in invasion as a separate field of study did not begin until the mid-1980s when the Scientific Committee on Problems of the Environment (SCOPE) commissioned a series of workshops on the topic (Simberloff 2011b, 2013).

Instead, Simberloff's first publications in ecology arose from his pioneering experimental test of Robert MacArthur and Edward Wilson's theory of Island Biogeography (MacArthur and Wilson 1963, 1967). Simberloff boldly undertook a wildly-ambitious project of fumigating entire mangrove island-a "defaunation" experiment-to empirically test how an island's size and distance from the mainland influenced species' colonization and extinction patterns (Simberloff 1969; Simberloff and Wilson 1969; Wilson and Simberloff 1969). Simberloff's drive, intelligence, and dedication to the project quickly gained respect from his thesis advisor, Wilson, who wrote in his memoir Naturalist, "I hesitate to use the usual expression "studied under me" because in the years to follow I learned as much from [Simberloff] as he did from me. We soon became partners" (Wilson 1994).

As a graduate student, Simberloff's research was rigorous, sometimes tedious, and also a huge academic risk. Simberloff's research took place in mosquitofilled mangrove islands in tropical south Florida, where he dealt with a myriad of troubles that are likely very familiar to most field ecologists. As Wilson recollects, "Simberloff, the city-bred mathematician, did well. He endured the insect bites and lonely hours in the hot sun I had promised him (Wilson 1994). Simberloff also recalls harrowing field times, "It was grueling, very grueling, sometimes physically unpleasant. Especially the sharks and mosquitoes! . . . To sample some of these islands, I had to anchor some distance away and wade to the island. I had to always keep an eye out for sharks, and sometimes hit them on the top of the head with an oar that I carried with me" (Sridhar 2018).

However, hard work was not the only hallmark of Simberloff's early research, Wilson notes, "By joining the project, Dan took a career risk" (Wilson 1994). If Simberloff and Wilson were unable to completely remove the arthropods from the islands, or to identify every arthropod species immigrating to the islands, or if it took decades for arthropods to recolonize the empty islands, Simberloff's thesis would have been a bust and he would have had to find another project for his dissertation. Unlike many graduate students who took on low-risk projects with more certain outcomes, Simberloff's studies contributed to the birth of a new 
subdiscipline of ecology, Island Biogeography (Wilson 1994).

Another key characteristic that has been a trademark of Simberloff's career is his unwavering insistence on the primacy of empirical evidence and the cautionary interpretations of limited data. Despite the elegance of the theoretical models, Simberloff's initial interest in Island Biography lay, in part, with his skepticism that islands could actually maintain a dynamic equilibrium of species (Simberloff and Wilson 2017). In line with his personal expectations, Simberloff pushes his students to embrace the study of natural history of systems and take on the task of utilizing creative experiments to test their ideas. As former graduate student Sharon Strauss recalls "Upon hearing my ideas, Dan delivered what I later realized was the ultimate insult, though I didn't appreciate it at the time-he called my ideas 'anecdotal.' He pushed me to figure out how to show these connections experimentally" (Henning et al. 2017).

While Simberloff eagerly undertook his own field experiments and encouraged his students to do the same, he also has always been modest and prudent about the shortcomings of any single study and overlybroad interpretations of limited number of studies, including his own dissertation research (Simberloff and Abele 1976; Sridhar 2018). It distressed Simberloff that scientists seemed to easily accept his dissertation research as proof of the dynamic equilibrium theory, and even worse, that scientists were applying the theory as indisputable evidence supporting major conservation decisions (Diamond 1975; Diamond et al. 1976; Simberloff 1976; Simberloff and Abele 1976; Sridhar 2018). While some advocated that conservationists should only preserve single, large tracts of land that would protect the largest number of species, as predicted by the theory of Island Biogeography (Diamond 1975), Simberloff argued that in some instances, several small areas could host more species than a single large area (Simberloff and Abele 1976). This debate - the first of many vigorous debates that punctuate Simberloff's career-became known in the field as the SLOSS (single large, or several small) debate. This debate was more than just an argument about the application of Island Biogeography theory. "This is not a plea, then, for a specific conservation regime," Simberloff and a colleague wrote in 1976, "but rather for more comprehensive autecological consideration... In sum, the broad generalizations that have been reported are based on limited and insufficiently validated theory and on field studies of taxa which may be idiosyncratic" (Simberloff and Abele 1976).

Beginning with the SLOSS debate and continuing throughout his career, Simberloff has eloquently and ardently advocated for researchers to embrace and appreciate the complexity of ecological systems. To that end, he champions local experimental studies that reveal the natural history and informative contingencies that each unique species assemblage and ecosystem offers (Simberloff and Abele 1976; Simberloff 2004, 2006; Ricciardi and Simberloff 2009; Simberloff et al. 2013). Instead of searching for concrete Laws and Theories of ecology, we should instead build a vast body of knowledge about individual groups of species and ecosystems that we can then mine for generalizable patterns. Simberloff writes: "Ecology isn't like physics. Physics has a rather limited number of particles-they're ever more, but even if they're a couple hundred, in ecology we're dealing not only with hundreds or thousands of species but, within each species, with many different genotypes ... that's vastly more complicated. So, a sort of statistical mechanical approach, like Boyle's Law or something, doesn't work. The systems are very idiosyncratic, so the best one can hope to do, in my opinion, for both ecology and for invasions, is a sort of set of approximate patterns or expectations to begin to look at. But each system is different. There are no laws of ecology as there are laws of thermodynamics, for example. There are always many outliers, there are clouds of points ... one can draw a regression line through it and there's enough points that it is significant, but it doesn't explain much of the variance at all. And what's important is to study why each point is where it is" (Santos 2016).

It is perhaps no surprise that in the early 1980s when the SCOPE organizers were convening workshops with eminent ecologists from around that globe, Simberloff was invited to join the conversation. These workshops, along with an invitation in 1986 to join the Board of Governors of The Nature Conservancy (TNC), shifted Simberloff's focus to the study of biological invasions. These roles, which concentrated Simberloff on practical conservation concerns, spurred him to look at species invasions more systematically, and it became clearer to him that species invasions were not only academically 
interesting, but also a significant conservation issue (Simberloff 2013; Grason 2014).

From the outset, Simberloff's contribution to shaping the field was evident. Some of his earlier publications on the topic, such as how to study the impacts of invasive species (Parker et al. 1999) and the new concept of 'invasional meltdown' (Simberloff and Von Holle 1999) are among the most highly-cited publications in the invasion literature. He has authored over 300 peer-reviewed journal articles and over 90 book chapters, many focused on the topic of invasions. As Editor-in-Chief of this journal, he has introduced The Elton Reviews (Meyerson and Simberloff 2017) and Floras and Faunas (Pyšek et al. 2017), new features that provide important platforms for the continued growth of the field.

Most importantly, however, as his publication and public speaking record shows, Simberloff is one of the leading voices calling for continued research on the biology of nonnative species and a unwavering supporter for the management of nonnative species to remain a top conservation priority (Parker et al. 1999; Simberloff 2005, 2008, 2013; Simberloff et al. 2012, 2013; Rejmánek and Simberloff 2017). His credibility as a scientist has allowed him to be a powerful advocate and champion for the field of study, which is demonstrated by the frequency in which he is interviewed by students, journalists, and popular science writers about the field (Grason 2014; Santos 2016; Goode 2016; Simmons 2016; Mooney 2016; Nuwar 2016; Evans-Brown 2016; Simon 2016).

Appreciation of and fascination with the nuances and intricacies of invasions, and the pressing need for management of species for conservation, laid a foundation for Simberloff's future contributions to the field.

Overlaid on this is the Simberloffian paradigm about how ecologists-including students-should approach research:

- We should embrace the complexity and idiosyncrasies of ecological systems

- We should not shy away from contingencies, which will require creative, ambitious, experimental studies that will likely require much hard and tedious work; and

- We should never broadly generalize about the Laws and Theories of ecology from a single study (including our own!), or even, a small set of studies of a few ecosystems.

These characteristics are exactly what we hope future students of invasion biology will strive to embody and emulate in their own early careers. Thus, it is not only fitting but necessary that we name this new award, recognizing students who demonstrate intelligence, creativity, tenacity, and passion, in honor of Dan Simberloff.

\section{References}

Diamond JM (1975) The island dilemma: lessons of modern biogeographic studies for the design of natural reserves. Biol Conserv 7:129-146

Diamond JM, Terborgh J, Whitcomb RF et al (1976) Island biogeography and conservation: strategy and limitations. Science 193:1027-1032

Evans-Brown S (2016) Introducing bugs as biocontrol for invasive species is more effective than we think. In: Slate. Accessed 21 Aug 2018

Goode E (2016) Invasive species aren't always unwanted. The New York Times, pp 1-9

Grason E (2014) Diverse introspectives: a conversation with Dan Simberloff. In: BioDiverse perspectives. http://www. biodiverseperspectives.com/2014/04/01/diverseintrospecives-a-conversation-with-dan-simberloff/. Accessed 17 Aug 2018

Henning JA, Leppanen C, Bush J et al (2017) A pioneering adventure becomes an ecological classic: the arising and established researchers. Bull Ecol Soc Am 98:270-276. https://doi.org/10.1002/bes2.1350

MacArthur RH, Wilson EO (1963) An equilibrium theory of insular zoogeography. Evolution 17:373-387

MacArthur RH, Wilson EO (1967) The theory of island biogeography. Princeton University Press, Princeton

Meyerson LA, Simberloff D (2017) Introducing “"The Elton Reviews", a new series in biological invasions. Biol Invasions 19:1053-1054. https://doi.org/10.1007/s10530017-1401-9

Mooney C (2016) This disease is killing California trees by the millions, but scientists urge against giving up. The Washington Post, pp 1-6

Nuwar R (2016) The global price of invasive species. In: Smithsonian. https://www.smithsonianmag.com/sciencenature/global-price-invasive-species-180959522/?no-ist. Accessed 21 Aug 2018

Parker IM, Simberloff D, Lonsdale WM et al (1999) Impact: toward a framework for understanding the ecological effects of invaders. Biol Invasions 1:3-19

Pyšek P, Meyerson LA, Simberloff D (2017) Introducing “Alien Floras and Faunas", a new series in Biological Invasions. Biol Invasions 20:1375-1376. https://doi.org/10.1007/ s10530-017-1648-1 
Rejmánek M, Simberloff D (2017) COMMENT: origin matters. Environ Conserv 44:97-99. https://doi.org/10.1017/ S0376892916000333

Ricciardi A, Simberloff D (2009) Assisted colonization is not a viable conservation strategy. Trends Ecol Evol 24:248-253. https://doi.org/10.1016/j.tree.2008.12.006

Santos MD (2016) What happens when a species is introduced in an area outside its geographic range? Daniel Simberloff interviewed for $\mathrm{cE} 3 \mathrm{c}$. In: Centre for ecology, evolution and environmental change. http://ce3c.ciencias.ulisboa.pt/ outreach/press\&events/ver.php?id=670. Accessed 17 Aug 2018

Simberloff DS (1969) Experimental zoogeography of islands: a model for insular colonization. Ecology 50:296-314

Simberloff D (1976) Species turnover and equilibrium island biogeography. Science 194:572-578

Simberloff D (2004) Community ecology: is it time to move on? Am Nat 163:787-799

Simberloff D (2005) Non-native species DO threaten the natural environment! J Agric Environ Ethics 18:595-607. https:// doi.org/10.1007/s10806-005-2851-0

Simberloff D (2006) Invasional meltdown 6 years later: important phenomenon, unfortunate metaphor, or both? Ecol Lett 9:912-919. https://doi.org/10.1111/j.1461-0248. 2006.00939.x

Simberloff D (2008) We can eliminate invasions or live with them. Successful management projects. Biol Invasions 11:149-157. https://doi.org/10.1007/s10530-008-9317-z

Simberloff D (2011a) Charles Elton: neither founder nor siren, but prophet. In: Richardson DM (ed) Fifty years of invasion ecology - the legacy of Charles Elton, 1st edn. WileyBlackwell, West Sussex, pp 11-24

Simberloff D (2011b) Charles Elton: neither founder nor siren, but prophet. In: Richardson DM (ed) Fifty years of invasion ecology: the legacy of Charles Elton. Wiley-Blackwell, Oxford, pp 11-24

Simberloff D (2012) Integrity, stability, and beauty: Aldo Leopold's evolving view of nonnative species. Environ Hist 17:487-511. https://doi.org/10.1093/envhis/ems044

Simberloff D (2013) Invasive species: what everyone needs to know. Oxford University Press, Oxford

Simberloff DS, Abele LG (1976) Island biogeography theory and conservation practice. Science 191:285-286
Simberloff D, Rejmánek M (eds) (2011) Encyclopedia of biological invasions. University of California Press, California

Simberloff D, Von Holle B (1999) Positive interactions of nonindigenous species: invasional meltdown? Biol Invasions 1:21-32

Simberloff DS, Wilson EO (1969) Experimental zoogeography of islands: the colonization of empty islands. Ecology 50:278-296

Simberloff D, Wilson E (2017) A pioneering adventure becomes an ecological classic: the pioneers. Bull Ecol Soc Am 98:276-277. https://doi.org/10.1002/bes2.1347

Simberloff D, Souza L, Nuñez MA et al (2012) The natives are restless, but not often and mostly when disturbed. Ecology 93:598-607

Simberloff D, Martin J-L, Genovesi P et al (2013) Impacts of biological invasions: what's what and the way forward. Trends Ecol Evol 28:58-66. https://doi.org/10.1016/j.tree. 2012.07.013

Simberloff D, Meyerson LA, Pyšek P, Richardson DM (2017) Honoring Harold A. Mooney: citizen of the world and catalyst for invasion science. Biol Invasions 19:2219-2224. https://doi.org/10.1007/s10530-017-1498$\mathrm{X}$

Simmons M (2016) Warm winter presents challenges to adelgid control. In: Knoxville news sentinel. http://archive. knoxnews.com/news/local/warm-winter-presentschallenges-to-adelgid-control-2ceb502a-635a-3bb7-e0530100007f4372-370547151.html/. Accessed 25 Aug 2018

Simon M (2016) To save an endangered fox, humans turned its home into a war zone. In: Wired. https:/www.wired.com/ 2016/08/save-endangered-fox-humans-turned-home-warzone/?utm_source=rss1.0\&utm_medium $=$ feed. Accessed 21 Aug 2018

Sridhar H (2018) Revisiting Simberloff and Wilson 1969. In: Reflections on past papers. https://reflectionsonpaperspast. wordpress.com/2018/03/12/revisiting-simberloff-andwilson-1969/. Accessed 17 Aug 2018

Wilson EO (1994) Naturalist. Island Press/Shearwater Books, Washington

Wilson EO, Simberloff DS (1969) Experimental zoogeography of islands: defaunation and monitoring techniques. Ecology 50:267-278 